\section{Jaffe-Lichtenstein Syndrome Associated with a Simple Bone Cyst: Unprecedented Rare Case Report}

Poliana Gonçalves Miranda ${ }^{1} \oplus$, João César Guimaraes Henriques²ำ, Luiz Fernando Barbosa de Paulo $^{3}{ }^{\circ}$, Cizelene do Carmo Faleiros Veloso Guedes ${ }^{4}{ }^{\circ}$, Fabio Franceschini Mitri ${ }^{\circ}{ }^{\circ}$, Cláudia Jordão Silva ${ }^{3}[0$
'UFU - Universidade Federal de Uberlândia, Uberlândia, MG, Brazil ${ }^{2}$ Oral Medicine Department, UFU - Universidade Federal de Uberlândia, Uberlândia, MG, Brazil ${ }^{3}$ Oral Maxillofacial Surgery and Traumatology Department, UFU - Universidade Federal de Uberlândia, Uberlândia, MG, Brazil ${ }^{4}$ Oral Oncology Department, UFU - Universidade Federal de Uberlândia, Uberlândia, MG, Brazil ${ }^{5}$ Human Anatomy Department, UFU - Universidade Federal de Uberlândia, Uberlândia, MG, Brazil

Correspondence: Poliana Gonçalves Miranda, Avenida Pará $n^{\circ} 1720$, 3840-5320 Uberlândia, MG, Brasil. Tel: +55-34-322-58118. e-mail: poliana.gm@hotmail.com
Key Words: polyostotic fibrous dysplasia, maxillary diseases, bone cysts.

\section{Introduction}

The term fibro-osseous used with reference to a diversified group of disorders, in which the normal bone architecture is replaced by fibroblasts, collagen fibers and immature bone (1). In these lesions a connective tissue matrix is identified, containing variable quantities of mineralized tissue that may be medullary or cementoid bone (1). According to the latest World Health Organization (WHO) classification, they form part of the group of fibro-osseous lesions, cemento-osseous dysplasia, fibrous dysplasia, ossifying fibroma and familial gigantiform cementoma (2). The simple bone cyst or idiopathic bone cavity has been related to fibro-osseous lesions, among them, florid cemento-osseous dysplasia is especially outstanding $(3,4)$.

Despite the uncertain etiology of fibrous dysplasia, the involvement of activating mutation in the GNAS1 gene has been widely described. This in turn encodes the Gs alpha protein in pluripotent embryonic stem cells, predisposing them to skeletal changes $(5,6)$. When this mutation occurs easily, during the period of embryonic life, there is a more generalized and severe manifestation of the disease, with multiple bones being affected, characterized as Polyostotic and eventually syndromic. Whereas if the mutation occurs in the postnatal period, a single bone is involved, denominated monostotic, with the gnathic bones being frequent sites of this involvement - unilaterally for the maxilla with a typical ground-glass aspect (7). With respect to the syndromic presentations associated with Polyostotic dysplasias, the Jaffe-Lichtenstein syndrome has been reported, which associates skin blemishes of the Café au lait type; the McCune-Albright syndrome, involving endocrine disorders as well as spots of the Café au lait type; and the Mazabraud syndrome, characterized by the involvement of intramuscular myxomas (8).

In view of the foregoing, the purpose of the present study was to report an unprecedented case in which the Jaffe-Lichtenstein syndrome was associated with an idiopathic bone cavity. The clinical, imaging, laboratory, histopathological and therapeutic characteristics involved in attendance of the patient will be reported.

\section{Case Report}

The patient, C.P.G., a 43 year-old man, caucasian, presented to the stomatology outpatient clinic complaining of an increase in volume in the region of the mandibular body on the right side, with a period of development of approximately 10 months associated with regional painful symptoms. Oroscopy revealed tumefaction in the region of the molars and premolars on the reported side, and 
mucosa with normal color (Fig. 1A and 1B). The patient brought with him printed helical computed tomography that had previously been taken, which showed craniofacial bone changes compatible with the ground glass aspect, in addition to a hypodense, well delimited lesion in the right mandibular body. A panoramic x-ray was then taken, allowing confirmation of the areas with the ground glass aspect, in addition to a large radiolucent lesion with relatively well defined limits, covering the region from absent 46 tooth, up to half of the ascendant ramus on the right side, associated with considerable thinning of the basilar cortical bone. (Fig. 2A and 2B) In view of the imaging exam findings and the uncoordinated gait with distinct shortening of the right leg perceived, the patient was asked about the eventual presence of blemishes on the body, and whether he had experienced skeletal problems throughout his life. To the team's surprise, the patient answered positively, saying that he had blemishes on his body and had a series of bone fractures that eventually required surgical procedures during his life. In a private

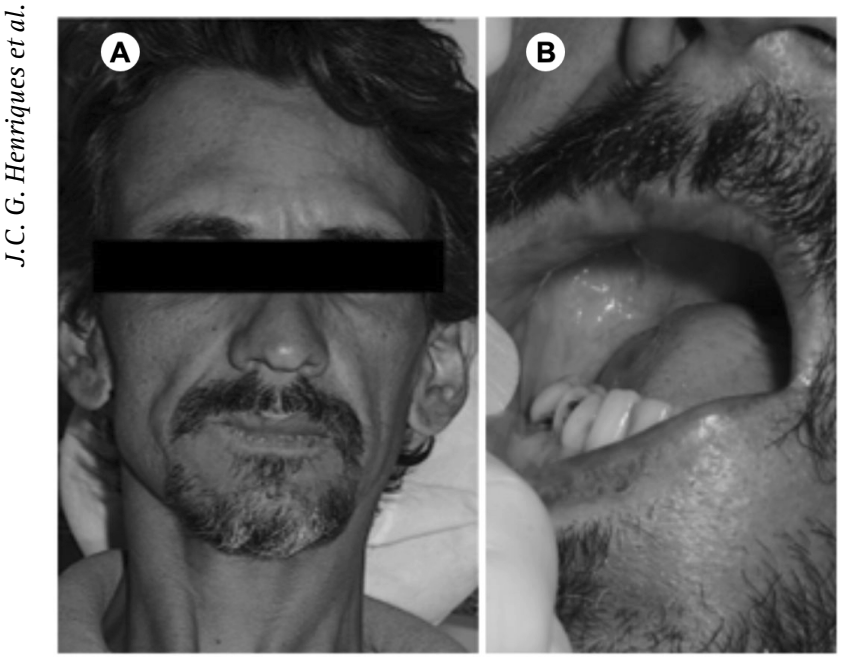

Figure 1. A: Extraoral photo showing normality. B: Oroscopy showing a curvature in the right mandibular body. environment, the patient showed the café au lait type spots widely distributed over the right side of the body. Furthermore, the new radiographic exams requested revealed changes in bone in other parts of the right side of the skeleton, such as the humerus, scapula, femur, tibia and fibula. Moreover, it was possible to perceive the fixation plate on the femur that had fractured years ago. (Fig. 3A, 3B and $3 \mathrm{C}$ ). The laboratory exams requested showed normality, with exception of the increase in the alkaline phosphatase levels (295.00 U/L - reference value $40-129 \mathrm{U} / \mathrm{L})$ and the patient denied any sexual precocity in childhood. Subsequently, with antibiotic coverage of $1 \mathrm{~g}$ amoxicillin, aspiration puncture was performed of the hyperdense area visualized in the mandibular body on the right side, which was positive for the content of bloody liquid. After this, the interior of the lesion was submitted to careful curettage for the purpose of performing anatomic pathology and histopathological exams. In view of all the findings, the hypothesis raised was that of Jaffe-Lichtenstein Syndrome in probable association with simple bone cyst. Important to point out is that up to now, the patient had no information about his possibly suspected condition.

Seven days after the intervention, the patient returned presenting a condition of osteomyelitis with fistula and purulent drainage collection. Clindamycin hydrochloride, $300 \mathrm{mg}$ every $8 \mathrm{~h}$ and mouth wash with $0.12 \%$ Chlorhexidine digluconate 2 times per day, for 7 days was prescribed. The microscopic result was compatible with fibro-osseous lesion associated with simple bone cyst. The patient was duly informed about the care he had to take with regard to his infirmity, especially relative to the greater general bone frailty and need to perform meticulous oral hygiene. The patient was also referred for dental care to eliminate foci of oral infection, tooth extractions and removal of carious tissues.

After the elapse of 2 months, a new panoramic $x$-ray was taken, showing centripetal bone neoformation, however, new curettage was planned with concomitant use of antibiotics (Clindamycin $300 \mathrm{mg}$ every $8 \mathrm{~h}$ ), to increase

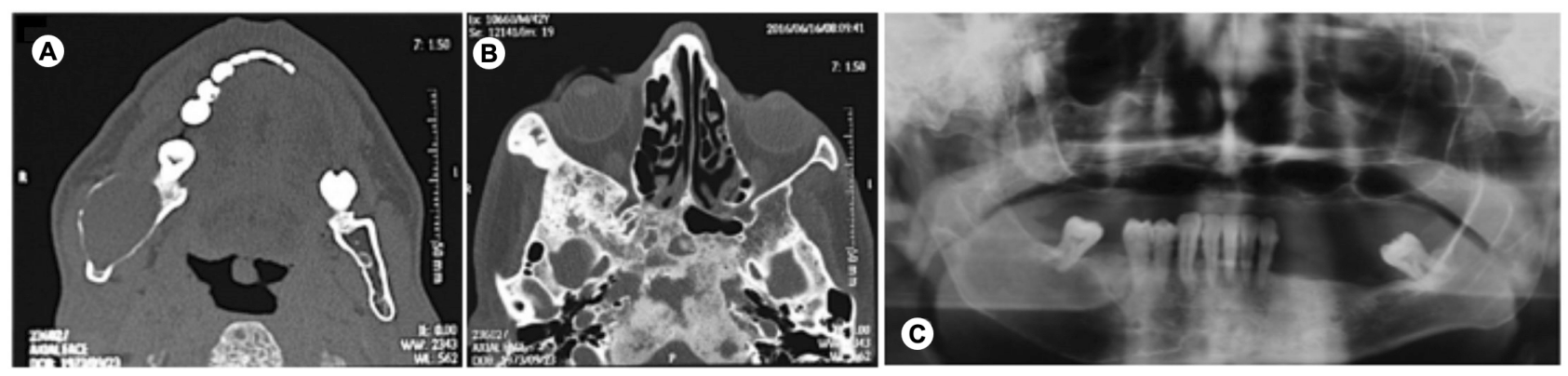

Figure 2. A: Axial slice of helical computed tomography showing the ground-glass aspect of craniofacial bones. B: Mandibular axial slice showing expansive hypodense lesion in the mandibular body on the right. C: Panoramic x-ray showing the bone cavity and areas of ground-glass aspect. 
bone neoformation within the bone cavity.

Panoramic x-rays were taken at 3-monthly time intervals and showed associated increase in bone neoformation of the simple bone cyst after the curettage procedure (Fig. 4). The patient was instructed to include stomatological follow-up treatment concomitantly with periodic orthopedic follow-up. At present the patient is asymptomatic, without foci of infection in the oral cavity, and completely aware of his general condition, and the need to prevent future complications.

\section{Discussion}

Fibrous dysplasia is a disease characterized as a benign bone developmental disorder, with slow progression, frequently associated with mutation of the GNAS1 gene and with stabilization after puberty $(5,9)$. Anatomic pathology and histopathological exams of fibro-osseous lesions may be rather similar, eventually making it difficult to distinguish between the existent variants. This explains the fundamental need for associating the clinical and imagining exam characteristics in determining the final diagnosis. In this context, it is worth pointing out that fibrous dysplasia shows asymptomatic volumetric increases, frequently unilateral, with an imaging manifestation of the groundglass aspect being commonly disseminated. Furthermore, increase alkaline phosphatase levels are common laboratory findings in affected individuals (9). In the present study, the craniofacial tomographic changes the patient brought with him showed the ground-glass aspect. These were the first signs used to investigate the fibrous dysplasia present. Observation of the patient who presented change in his gait led the authors to investigating the skeletal changes, proved by radiographic exams performed. Questioning the patient about the presence of blemishes on the body associated with the absence of sexual precocity and increased alkaline phosphatase levels, led to the diagnosis of Polyostotic
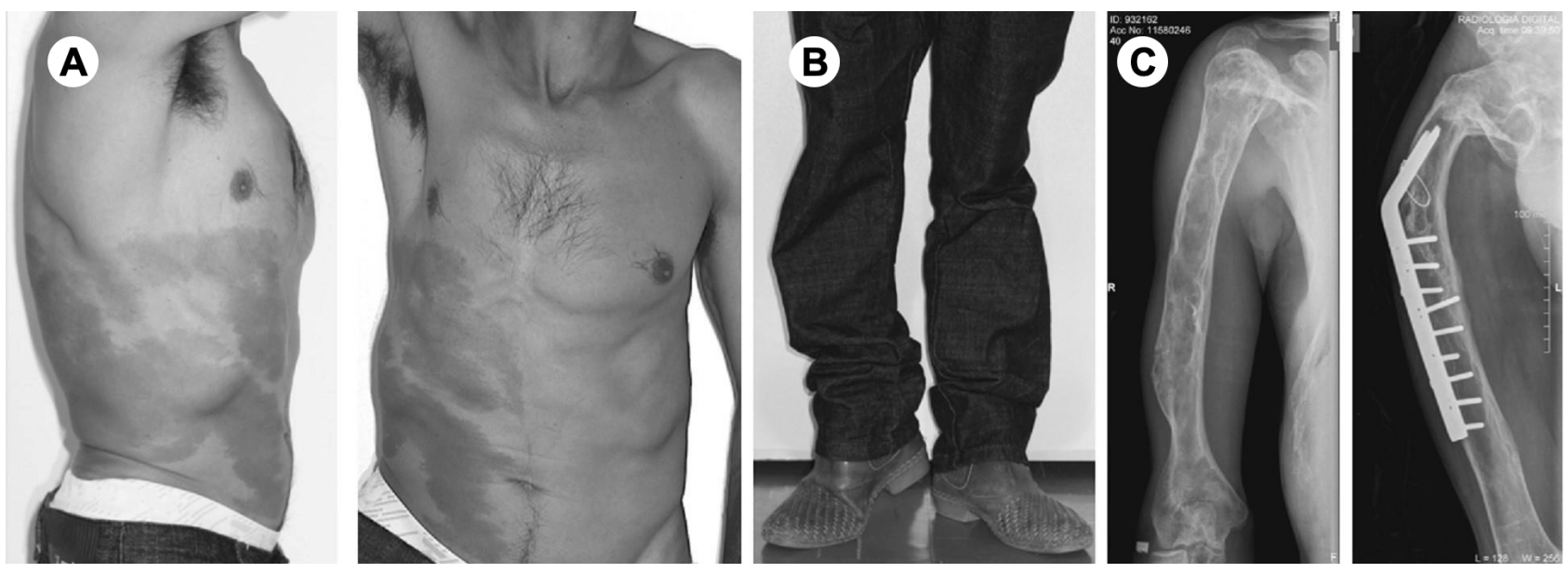

Figure 3. A: Café au lait type spots on right side of patient's body. B: Right leg with shorter length than left leg. C: Right humerus with morphological change and radiopacity, and previously fractured femur with fixation plate.

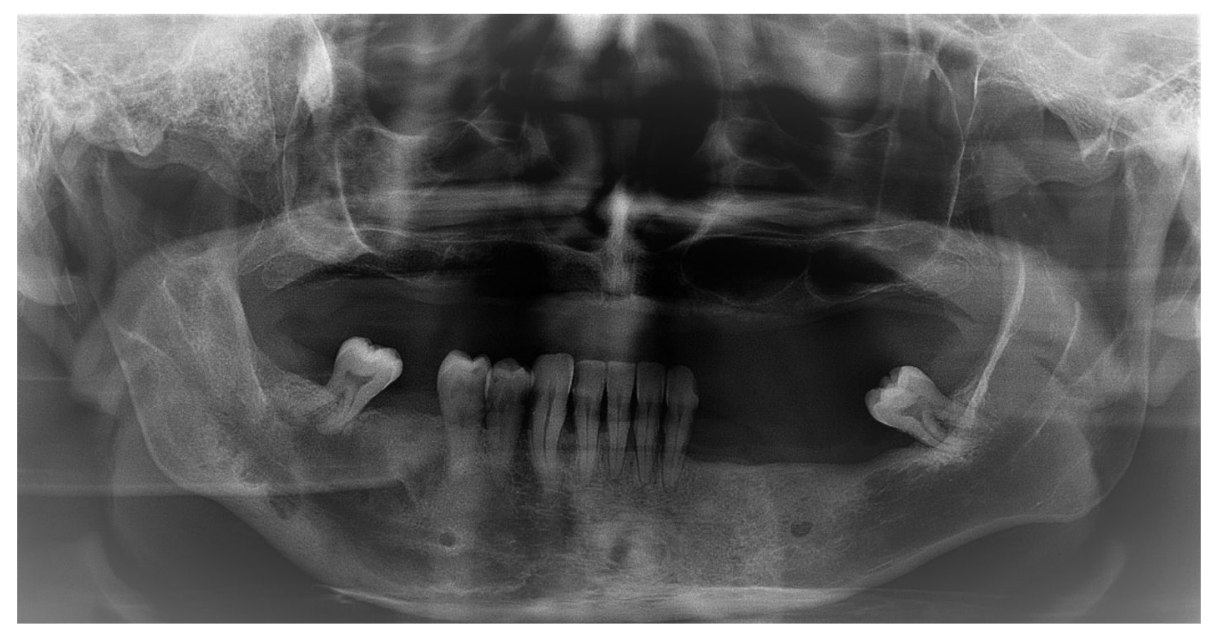

Figure 4. Panoramic x-ray taken after 15 months follow-up, revealing good centripetal bone neoformation in the region of the simple bone cyst. 
fibrous dysplasia manifested by the rare syndromic form of Jaffe-Lichtenstein.

The simple bone cyst or idiopathic bone cavity is a bone lesion frequently found, especially in gnathic and long bones of youngsters in the second decade of life (3). The literature has reported an important association of these lesions with a specific type of fibro-osseous lesion - florid cemento-osseous dysplasia $(4,10)$. When associated with fibro-osseous lesions, simple bone cysts do not present the same response with satisfactory bone neoformation, verified after a procedure of curettage in younger patients. Thus, the chance that infectious conditions will be manifested is high, due to the low reparative quality of the bone itself that delimits the bone cavity (3). The present case showed a rare association of Polyostotic fibrous dysplasia, in the form of the Jaffe-Lichtenstein syndromes, with a mandibular simple bone cyst. Associations of fibrous dysplasias with simple bone cysts are extremely rare and up to now, there has been no report of the rare JaffeLichtenstein syndrome with this mandibular bone cavity. Important to point out is that even with prior antibiotic coverage, there was a condition of osteomyelitis after the $\dot{*}$ initial curettage performed, confirming the difficulty of $\Xi$ bone cavity repairs occurring when they are associated with fibro-osseous lesions. Fortunately, after two curettage procedures and powerful antibiotic therapy administered there was satisfactory bone neoformation and the patient was asymptomatic.

Polyostotic fibrous dysplasias are important conditions that lead to serious consequences for affected patients, both in terms of esthetic questions and especially of their functionalities throughout their lives (11). In view of the conclusive diagnosis, due guidance and medication therapies, such as bisphosphonates, calcitonin and other anti-resorptive drugs have been used $(11,12)$, with the purpose of minimizing the skeletal changes and strengthening the bones in a general manner. Furthermore, orthopedic surgeries, bone grafts, internal fixation of the long bones and reduction of fractures are procedures routinely present in the lives of patients affected, with the aim of ameliorating the symptoms and minimizing comorbidities (13). The patient of the present case presented to the stomatology outpatient clinic with a history of diverse bone fractures throughout life. It was possible to identify the fixation plate on the right femur, in addition to diverse other reports of less serious fractures. Important to point out is the fact that the patient had never been informed about his pathological condition, in spite of having been submitted to diverse medical consultations, especially orthopedists. Therefore, the diagnosis defined in the stomatology outpatient clinic was crucial to enable to patient to become aware of his condition. Thus he will be able continue with his life taking the due care and necessary precautions to minimize future skeletal problems, following a healthy diet rich in calcium, bearing in mind the need for periodic professional monitoring.

The Jaffe-Lichtenstein syndrome is one of the rare syndromes possibly related to Polyostotic fibrous dysplasia, of which the association with idiopathic bone cavity has never before been reported in the world literature. Stomatology may play an essential role in the diagnosis of this condition, by providing actions and due guidance that will enable individuals affected to have the best possible quality of life.

\section{Resumo}

As denominadas lesões fibro-ósseas dos maxilares constituem um grupo diversificado de desordens nas quais a arquitetura óssea normal é substituída por fibroblastos, fibras colágenas e osso imaturo. Atualmente a Organização Mundial de Saúde reconhece quatro variantes destas lesões, sendo elas: a displasia cemento-óssea, a displasia fibrosa, o fibroma ossificante e cementoma gigantiforme familiar. A displasia fibrosa pode ser apresentar na forma monostótica, acometendo um único osso ou a região craniofacial isoladamente, e a forma poliostótica, envolvendo dois ou mais ossos do esqueleto, com eventual associação com condições sindrômicas. Paciente C.P.G., 43 anos, procurou atendimento devido aumento volumétrico sintomático na região de corpo mandibular do lado direito. Exames imaginológicos revelaram áreas craniofaciais com aspecto de vidro fosco ou despolido, além de extensa lesão radiolúcida mandibular. Durante o exame físico foram identificadas manchas do tipo café com leite dispostas do lado direito do corpo, além de marcha descoordenada com nítido encurtamento da perna direita. Novos exames radiográficos evidenciaram a disseminação esquelética da doença. 0 paciente negou qualquer precocidade sexual e o diagnóstico final foi de displasia fibrosa, expressa por meio da síndrome de Jaffe-Linchtenstein, em associação com um cisto ósseo simples.

\section{References}

1. Kramer IRH, Pindborg JJ, Shear M. The World Health Organization histological typing of odontogenic tumours. Introducing the second edition. Eur J Cancer Part B Oral Oncol 1993;29:169-171.

2. Wright JM, Vered M. Update from the 4th Edition of the World Health Organization Classification of Head and Neck Tumours: Odontogenic and Maxillofacial Bone Tumors. Head Neck Pathol Springer US 2017;11:68-77.

3. Mahomed F, Altini M, Meer S, Coleman H. Cemento-osseous dysplasia with associated simple bone cysts. J Oral Maxillofac Surg 2005;63:1549-1554.

4. Kuhmichel A, Bouloux GF. Multifocal Traumatic Bone Cysts: Case report and current thoughts on etiology. J Oral Maxillofac Surg 2010;68:208212.

5. Lee SE, Lee EH, Park H, Sung JY, Lee HW, Kang SY, et al. The diagnostic utility of the GNAS mutation in patients with fibrous dysplasia: Metaanalysis of 168 sporadic cases. Hum Pathol 2012;43:1234-1242.

6. Pereira T dos SF, Gomes CC, Brennan PA, Fonseca FP, Gomez RS. Fibrous dysplasia of the jaws: Integrating molecular pathogenesis with clinical, radiological, and histopathological features. J Oral Pathol Med 2019;48:3-9.

7. MacDonald DS. Maxillofacial fibro-osseous lesions. Clin Radiol 2015;70:25-36.

8. Baumhoer D. Bone-Related Lesions of the Jaws. Surg Pathol Clin 2017;10:693-704.

9. Eversole R, Su L, EIMofty S. Benign fibro-osseous lesions of the craniofacial complex a review. Head Neck Pathol 2008;2:177-202. 
10. Wakasa T, Kawai N, Aiga H, Kishi K. Management of florid cementoosseous dysplasia of the mandible producing solitary bone cyst: report of a case. J Oral Maxillofac Surg 2002;60:832-835.

11. Lee JS, Fitzgibbon EJ, Chen YR, Kim HJ, Lustig LR, Akintoye SO, et al. Clinical guidelines for the management of craniofacial fibrous dysplasia. Orphanet J Rare Dis 2012;7:S2.

12. Davidova LA, Bhattacharyya I, Islam MN, Cohen DM, Fitzpatrick SG. An analysis of clinical and histopathologic features of fibrous dysplasia of the jaws: a series of 40 cases and review of literature. Head Neck Pathol 2019:13:1-9.

13. Stanton RP, Ippolito $E$, Springfield D, Lindaman L, Wientroub $S$, Leet A. The surgical management of fibrous dysplasia of bone. Orphanet $J$ Rare Dis 2012;7:S1.

Received December 2, 2019 Accepted March 12, 2020 